\title{
Induction of Ovulation with Synthetic Gonadotrophin- Releasing Hormone in Women with Constant Anovulation Induced by Contraceptive Steroids
}

\author{
JUAN ZANARTU, ALFREDO DABANCENS， ROGELIO RODRIGUEZ-BRAVO，ANDREW V. SCHALLY
}

British Medical fournal, 1974, 1, 605-608

\section{Summary}

The ovarian response to stimulation with folliclestimulating hormone/luteinizing hormone-releasing hormone (FSH/LH-RH) was studied in young, healthy, and fertile women with constant iatrogenic anovulation caused by depot medroxyprogesterone acetate or depot chlormadinone acetate injected for contraceptive purposes. Results were compared with those in unstimulated controls. The response was observed directly on the ovaries at laparotomy performed after treatment with FSH/LH-RH. A wedge biopsy provided ovarian tissue for histological and histochemical studies of steroid dehydrogenase activity. Treatment with FSH/LH-RH caused a trophic effect on the ovaries, with evidence of follicular development; ovulation occurred in two out of 16 treated women. Preovulatory mature follicles were found in three others.

Clearly the FSH/LH-RH-induced release of FSH and LH caused follicular growth up to Graafian follicles, mature preovulatory follicles, and ovulation. Mitosis in granulosa and theca cells was also observed. A wide individual variation in gonadal response to hypothalamic FSH/LH-RH was evident, however. Nonetheless, our data support the possibility that treatment with FSH/LH-RH may prove valuable in patients with anovulatory sterility of hypothalamic origin.

\section{Introduction}

Numerous reports have documented the release of folliclestimulating hormone (FSH) and luteinizing hormone (LH) from the pituitary in animals and humans in response to stimulation with natural or synthetic hypothalamic LH- and FSHreleasing hormone (FSH/LH-RH). (Kastin et al., $1972 \mathrm{a}$; Schally et al., 1971 a; Schally et al., 1971 b). It has been clearly shown that the pituitary gland releases mostly LH but also FSH after FSH/LH-RH is injected subcutaneously, intramuscularly, or intravenously. The respon:e seems to be doserelated. Endogenous FSH and LH released under these conditions stimulate the gonads, as shown by the steroids secreted. (Schally et al., 1972; Kastin et al., 1972 b; Yen et al., 1972; Zarate et al., 1972). The study of the gonadal response from the viewpoint of ovulation or spermatogenesis, however, is most important for further assessment of the true potential value of

Jose J. Aguirre University Hospital, University of Chile Medical School, Santiago, Chile

JUAN ZANARTU, M.D., Professor of Obstetrics and Gynaecology

ALFREDO DABANCENS, M.D., Assistant Professor, Unit for Fertility Research and Section in Reproductive Pathology

ROGELIO RODRIGUEZ-BRAVO, M.D., Senior Surgeon and Professor, Centre for the Study of Reproductive Biology

Tulane University School of Medicine, and Veterans Administration Hospital, New Orleans, Louisiana, U.S.A.

ANDREW V. SCHALLY, PH.D., Professor of Medicine
FSH/LH-RH in the treatment of sterility and infertility. (Zarate et al., 1972; Zanartu et al., 1974; Akande et al., 1972).

Pituitary gonadotrophic hormones have both a mitotic action, stimulating follicular growth, and a steroidogenic effect. When the mature follicle is ripe $\mathrm{LH}$ forces its rupture and the ovum is released. Since the release of FSH and LH and the resulting hormonal changes in the gonads after injection of FSH/LH-RH have been shown in man and other mammals, we fe't that it would be interesting to study the follicular growth and the mitotic and ovulatory response at the ovarian level after FSH/LH-RH stimulation. Modifications which resulted from the steroidal response in other indirect indices were also investigated. In carrying out the study we used an experimental model in which constant iatrogenic anovulation existed as a result of the administration of injectable depot medroxyprogesterone acetate (MPA) and depot chlormadinone acetate (CA) for contraceptive purposes. We expected that more information could be obtained about the effect of FSH/LH-RH on human ovaries and ovulation by directly observing both ovaries at a laparotomy performed for elective tubal sterilization. We thought this could be substantiated by histological and histochemical studies of the structures stimulated and by a comparison with findings in untreated controls.

\section{Patients and Methods}

Fifty-seven apparently healthy women, aged 20 to 42 years and known to be fertile, participated in the study. They had all asked for tubal sterilization because of high multiparity. In each case both the husband and the wife had signed a request form after an attending physician and social worker had explained the surgical procedure. The whole investigation was considered and approved by a specially appointed ethical committee at the University Maternity Hospital. Each case had to be approved by at least four of the six physicians on the committee. The clinician in charge carefully explained the preoperative studies to each patient and that at operation a wedge biopsy would be made of one ovary and that one oviduct would be removed for morphophysiological studies.

We assumed from their previous pregnancies that all the women had a normally functioning hypothalamic-pituitarygonadal axis. Constant iatrogenic anovulation as a contraceptive measure was then induced in all of them by the administration of either long-acting depot MPA or depot CA. The MPA was injected intramuscularly in doses of 250 or $300 \mathrm{mg}$ every six months or $150 \mathrm{mg}$ every three months, the $\mathrm{CA}$ in doses of $250 \mathrm{mg}$ every two-and-a-half to three months or $150 \mathrm{mg}$ every two months. These progestogens are potent contraceptives. (Zanartu et al., 1970; Zanartu and Onetto, 1974).

The 57 participants were divided into a control group and an experimental group. The control group consisted of 41 women who had been on the contraceptive regimen for more than 12 months. They were then examined at laparotomy for tubal sterilization or for therapeutic hysterectomy. The experimental group consisted of 16 women who had also followed the contraceptive regimen. While they were still affected by the MPA or $\mathrm{CA}$-as shown by marked progestational modifications in such target organs as vagina, cervix, and endometrium-they were given stimulatory treatment with synthetic hypothalamic FSH/ 
LH-RH. The substance used was a decapeptide with the composition and amino-acid sequence described by Schally et al. (1971 b, and 1972).

Since the individual or total dose required for ovarian stimulation was not known the experimental group was further divided into four subgroups, each of which received a different total dose of FSH/LH-RH intramuscularly or by intravenous infusion (see table II) to try to find the most effective dosage in terms of follicular growth, maturation, and rupture with corpus luteum development. Total doses of less than $1 \mathrm{mg}, 1$ to $1.5 \mathrm{mg}$, 1.5 to $2 \mathrm{mg}$, and more than $2 \mathrm{mg}$ were administered. The individual intramuscular dose ranged from 0.05 to $0.1 \mathrm{mg}$ injected once or twice a day over a period of seven to 20 days. All intravenous administration was in the form of infusions, lasting five hours or longer, of $0.5 \mathrm{mg}$ in a $500 \mathrm{ml}$ isotonic glucose solution.

Because of reports that intravenous infusions were most effective (Zarate et al., 1972) the first trials were with five- to seven-hour intravenous infusions every second day. Because this proved inconvenient to patients, however, and because it failed to elicit any marked oestrogenic response, we adopted a regimen of one daily intramuscular injection for seven to 20 days followed by a single intravenous infusion once the intramuscular treatment had induced modifications in the cervical and vaginal indices suggesting endogenous oestrogen secretion. Subsequently we increased the number of intramuscular injections to two a day for the same number of days before giving the single intravenous infusion.

Several criteria were used in deciding when to change from intramuscular injections to intravenous infusions. Endogenous progesterone secretion was estimated from 24-hour urinary pregnanediol excretion, which was routinely studied the day before treatment and before laparotomy, using a thin-layer chromatography method (Sulimovici et al., 1965). The endogenous secretion of oestrogens was evaluated indirectly by biological criteria (vaginal cytology and kariopicnotic index, modifications in the physico-chemical properties of cervical mucus, and cervical os opening). An endometrial biopsy was taken the day before laparotomy.

After treatment the patients were explored at laparotomy 12 hours to 11 days after the final dose of FSH/LH-RH. The uterus, oviducts, and both ovaries were examined by direct visual and manual inspection. The presence of bloody fluid in the peritoneal cavity (pouch of Douglas), signs of ovulation, corpus luteum, cystic follicles, follicular cysts, or an apparently mature follicle were carefully recorded. Photographs were taken in all cases. A wedge biopsy was made in the ovary containing the functional structures estimated to be most significant-that is, mature follicle, corpus luteum, cystic follicle, and follicular cyst. The tissue sample was divided into two portions: one for histological study and the other, frozen with dry ice and sectioned at 16 microns thickness in a cryostat at minus $20^{\circ} \mathrm{C}$, for investigation of enzyme activity related to delta-5,3-betahydroxysteroid dehydrogenase (3- $\beta-\mathrm{OHD})$ and 20-alphahydroxysteroid dehydrogenase $(20-\alpha-O H D)$. The methods we used have been described elsewhere (Zanartu et al., 1970) and also our classification of the follicular apparatus (Zanartu et al., 1970; Zanartu and Onetto, 1974).
The diagnosis of a fully mature, non-ruptured follicle was based on the macroscopic aspect and the histologic evidence of well-developed granulosa cells and internal and external theca cell layers. The presence of numerous mitoses in these cells was considered an important sign of gonadotrophic stimulation. They were counted on tissue sections by a semi-quantitative method and recorded in arbitrary units ( 0 to $3+)$.

\section{Results}

\section{CONTROL GROUP}

At laparotomy the ovaries of women in the control group appeared normal in shape but they were about two-thirds of the normal ovulatory size (table I). They were whitish in colour, had a smooth surface, and contained from one to three cystic follicles and, occasionally, one or two follicular cysts. No evidence of ovulation or corpus luteum was seen on direct inspection or microscopically (Zanartu et al., 1970; Zanartu and Onetto, 1974). Though there were normal-appearing follicles up to the Graafian stage and atretic follicles there was no mitosis nor was enzymatic activity of steroid-converting dehydrogenases (3- $\beta-O H D$ or $20-\alpha-O H D)$ ever present.

It was assumed from these findings that the ovaries were in a "resting," anovulatory condition. This was shown by the fact that though follicular growth up to the Graafian stage persisted and there was some luteinization of the theca there was no evidence of steroid-converting dehydrogenase activity.

\section{EXPERIMENTAL GROUP}

All patients in the experimental group, whose ovaries had been stimulated by $\mathrm{FSH} / \mathrm{LH}-\mathrm{RH}$, presented slight to marked evidence of ovarian stimulation in terms of size. The ovaries consisted of a number of cystic follicles. In two patients there was bloody fluid in the peritoneal cavity. A congested uterus, oviducts, and ovaries were found in the presence of a mature follicle or fresh corpus luteum in five women. Biopsy confirmed the existence of fresh haemorrhagic corpus luteum in two patients. In three further patients the biopsy tissue contained luteinized follicles with well-developed theca and granulosa cells and with mitosis $(1+$ to $2+)$. In these structures steroidconverting dehydrogenase activity for $3-\beta-O H D$ was positive.

The stimulatory effect of FSH/LH-RH manifested itself in mild to moderate signs of oestrogenic changes in the vaginal cytology and cervical gland secretion, with a switch from progestational to oestrogenic characteristics. Endometrial histology, however, was not modified. It was also apparent that the intramuscular injection of synthetic FSH/LH-RH caused definite stimulation in "resting" ovaries with suppressed ovulation in terms of mitotic and steroidogenic FSH- and LH-like effects in those women receiving the optimum dosage (table II).

\section{Discussion}

Previous clinical studies have shown that MPA is an effective

TABLE I-Control Group of Women with Constant Iatrogenic Anovulation caused by Long-acting Injectable Progestogens

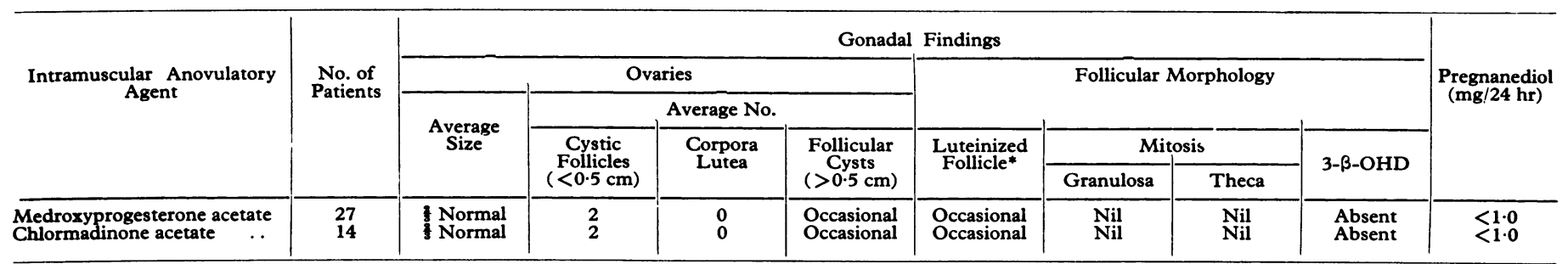

*Cystic follicle with luteinized theca. 
TABLE II-Results of Treatment with Synthetic FSH/LH-RH in 16 Women with Constant Iatrogenic Anovulation

\begin{tabular}{|c|c|c|c|c|c|c|c|c|c|c|c|c|c|c|}
\hline \multirow{3}{*}{\multicolumn{2}{|c|}{$\begin{array}{c}\text { Anovulatory } \\
\text { Agent } \\
\text { No. of Patients }\end{array}$}} & \multicolumn{4}{|c|}{ FSH/LH Treatment } & \multirow{4}{*}{$\begin{array}{c}\text { Time between } \\
\text { End of } \\
\text { FSH/LH } \\
\text { Treatment and } \\
\text { Laparotomy }\end{array}$} & \multicolumn{7}{|c|}{ Gonadal Findings } & \multirow{4}{*}{$\begin{array}{c}\text { Pregnanediol } \\
(\mathrm{mg} / 24 \mathrm{hr})\end{array}$} \\
\hline & & \multirow{3}{*}{$\underset{\text { (Days) }}{\text { Duration }}$} & \multicolumn{2}{|c|}{ No. of Injections } & \multirow{3}{*}{$\begin{array}{l}\text { Total } \\
\text { Dose } \\
\text { (mg) }\end{array}$} & & \multicolumn{3}{|c|}{ Ovaries } & \multicolumn{4}{|c|}{ Follicular Morphology } & \\
\hline & & & \multirow{2}{*}{$\begin{array}{l}\text { I.M. } \\
(\mathrm{mg})\end{array}$} & \multirow{2}{*}{$\begin{array}{c}\text { I.V. } \\
\text { Infusion } \\
\text { (mg) }\end{array}$} & & & \multirow[b]{2}{*}{ Size } & \multirow{2}{*}{$\begin{array}{c}\text { Cystic } \\
\text { Follicles }\end{array}$} & \multirow{2}{*}{$\begin{array}{c}\text { Corpora } \\
\text { Lutea } \\
\text { R/L } \\
\text { Ovary }\end{array}$} & \multirow{2}{*}{$\begin{array}{c}\text { Luteinized } \\
\text { Follicle }\end{array}$} & \multicolumn{2}{|c|}{ Mitosis! } & \multirow{2}{*}{ 3- $\beta-$} & \\
\hline MPA & $\mathbf{C A}$ & & & & & & & & & & $\begin{array}{l}\text { Gran- } \\
\text { ulosa }\end{array}$ & Theca & & \\
\hline 3 & 2 & $\begin{array}{l}14 \\
12 \\
10 \\
11 \\
14 \\
10 \\
10 \\
11 \\
19\end{array}$ & $\begin{array}{l}8 \times 0.05 \\
24 \times 0.025 \\
14 \times 0.05 \\
12 \times 0.05 \\
18 \times 0.05 \\
10 \times 0.1 \\
16 \times 0.1 \\
16 \times 0.1 \\
16 \times 0.05\end{array}$ & $\begin{array}{l}1 \times 0.5 \\
1 \times 0.5 \\
1 \times 0.5 \\
1 \times 0.5\end{array}$ & $\begin{array}{l}0.4 \\
0.6 \\
0.7 \\
1.1 \\
1.4 \\
1.5 \\
1.6 \\
1.6 \\
1.6\end{array}$ & $\begin{array}{l}15 \mathrm{hr} \\
10 \text { days } \\
2 \text { days } \\
18 \mathrm{hr} \\
2 \text { days } \\
16 \text { hr } \\
3 \text { days } \\
2 \text { days } \\
2 \text { days }\end{array}$ & 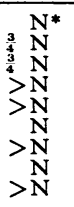 & $\begin{array}{l}5 \\
0 \\
3 \\
5 \\
4 \\
5 \\
5 \\
3\end{array}$ & $0 / 1$ & $\begin{array}{l}+ \\
\text { Preovul. } \\
\text { C. Lut. } \\
+ \\
\text { Preovul. } \\
+ \\
+ \\
+\end{array}$ & $\begin{array}{r}+ \\
+ \\
+ \\
2+ \\
+\end{array}$ & $\begin{array}{r}+ \\
+ \\
2+ \\
+\end{array}$ & $\begin{array}{l}\text { Present } \\
\text { Present } \\
\text { Present } \\
\text { Present }\end{array}$ & $\begin{array}{c}<1.0 \\
<1.0 \\
1.57 \\
1.77 \\
<1.0 \\
<1.0 \\
1.41 \\
<1.0 \\
1.32\end{array}$ \\
\hline 3 & 1 & $\begin{array}{l}19 \\
20 \\
22 \\
14 \\
16 \\
10 \\
12\end{array}$ & $\begin{array}{l}24 \times 0.1 \\
26 \times 0.05 \\
26 \times 0.05 \\
26 \times 0.05 \\
16 \times 0.1 \\
19 \times 0.1 \\
16 \times 0.1\end{array}$ & $\begin{array}{l}1 \times 0.5 \\
1 \times 0.5 \\
1 \times 0.5 \\
1 \times 0.5 \\
1 \times 0.5 \\
5 \times 0.5 \\
2 \times 0.5\end{array}$ & $\begin{array}{l}1.7 \\
1.8 \\
1.8 \\
2.1 \\
2.4 \\
2.5 \\
2.6\end{array}$ & $\begin{array}{l}8 \text { days } \\
6 \text { days } \\
2 \text { days } \\
15 \text { hr } \\
2 \text { days } \\
7 \text { days } \\
5 \text { days }\end{array}$ & $\begin{array}{r}>\mathbf{N} \\
\stackrel{N}{N} \\
>\mathbf{N} \\
>\mathbf{N} \\
\mathbf{N}\end{array}$ & $\begin{array}{l}5 \\
4 \\
4 \\
3 \\
4 \\
4 \\
3\end{array}$ & $0 / 1$ & $\begin{array}{l}\text { Preovul. } \\
+ \\
\begin{array}{l}+ \\
\text { C. Lut. } \\
+ \\
+\end{array}\end{array}$ & $\begin{array}{l}+ \\
2+ \\
2+ \\
2+ \\
2+\end{array}$ & $\begin{array}{l}3+ \\
+ \\
+ \\
2+ \\
2+ \\
2+\end{array}$ & $\begin{array}{l}\text { Present } \\
\text { Present }\end{array}$ & $\begin{array}{l}<1.0 \\
<1.0 \\
<1.0 \\
1.74 \\
<1.0 \\
<1.0 \\
1.73\end{array}$ \\
\hline
\end{tabular}

$* \mathrm{~N}=$ Normal.

+Graded on scale 0-3 +. See text.

contraceptive for at least six months when administered in doses of 250 or $300 \mathrm{mg}$ intramuscularly and is effective for at least three months in doses of $150 \mathrm{mg}$ intramuscularly. The period of ovulation inhibition was two months for $150 \mathrm{mg}$ CA intramuscularly and three months for $250 \mathrm{mg}$ CA intramuscularly. At the end of these periods spontaneous ovulation tends to reappear (Zanartu et al., 1970). We therefore assume that it would be easier to induce ovulation towards the end of the period during which the anovulatory agents remained active. Our findings in this admittedly limited study, however, do not confirm this hypothesis. While they confirm the FSH- and LHreleasing effect of the synthetic hypothalamic hormone, there was much individual variation in the response to stimulation. These variations seemed totally unrelated to the anovulatory agent itself or to the time after the last dose of MPA or CA at which the stimulatory agent was given (table III).

Evidently a total dose of FSH/LH-RH of less than $1.0 \mathrm{mg}$, even if given by slow intravenous infusion, had only a weak ovarian stimulatory effect under our experimental conditions. On the other hand, rather high doses $(2.1$ to $2.6 \mathrm{mg})$ were more effective and they did not produce a hyperstimulation syndrome in the four women to whom they were given. In three women we were able to induce preovulatory follicles characterized by well-developed and evenly distributed granulosa and theca cell layers, with mitosis and signs of external theca vascularization, and in two further patients the treatment brought about fresh haemorrhagic corpora lutea.
Under these experimental conditions the ovulation rate was less than $30 \%$ even when the preovulatory follicles were counted. We are now trying to determine whether prolonged stimulation with FSH/LH-RH would induce more ovulations. Up to five prolonged intravenous infusions of $0.5 \mathrm{mg} \mathrm{FSH} / \mathrm{LH}-\mathrm{RH}$ produced only a preovulatory follicle in one patient. Numerous mitoses and granulosa cells were present. The optimum stimulation was apparently produced by giving small intramuscular injections repeated every 12 hours until signs of follicular maturation presented and then a bosster dose of $0.5 \mathrm{mg}$ by intravenous infusion.

These preliminary observations suggest that repeated smalldose stimulation is more effective than larger single doses. Earlier investigations also suggest that prolonged intravenous infusions may be as effective as small intramuscular doses repeated every six or eight hours daily. These findings point to a prolonged and continuous $\mathrm{FSH} / \mathrm{LH}-\mathrm{RH}$ stimulation for a period of 10 or more days as a possible means of stimulating follicular growth and increasing the ovulation rate. Our findings suggest that a long-acting depot preparation of FSH/LH-RH would be more convenient for therapeutic use.

The fact that treatment with FSH/LH-RH induced ovulation and development of the corpus luteum in some of our patients supports the view that it may prove valuable in patients with anovulatory sterility of hypothalamic origin. We would emphasize, however, that we have not yet found a therapeutic regimen with this agent that consistently gives an ovulation rate similar

TABLE III-Doses of FSH/LH-RH and Progestogen Contraceptives and Interval between Treatments in 16 Women with Iatrogenic Anovulation

\begin{tabular}{|c|c|c|c|c|c|c|}
\hline \multicolumn{2}{|c|}{ FSH/LH-RH Treatment } & \multicolumn{3}{|c|}{ Long-acting Progestogen Contraception } & \multirow{2}{*}{$\begin{array}{l}\text { No. of Months } \\
\text { between Last Dose } \\
\text { of MPA or CA } \\
\text { and FSH/LH } \\
\text { Treatment }\end{array}$} & \multirow[b]{2}{*}{ Gonadal Response to FSH/LH Treatment } \\
\hline $\begin{array}{l}\text { Total Dose } \\
\text { (mg) }\end{array}$ & $\begin{array}{c}\text { Duration of } \\
\text { Treatment } \\
\text { (Days) }\end{array}$ & $\begin{array}{r}\text { Do } \\
\text { MPA }\end{array}$ & CA & $\begin{array}{l}\text { Duration of } \\
\text { Treatment } \\
\text { (Months) }\end{array}$ & & \\
\hline $\begin{array}{r}<1.0: \\
0.4 \\
0.6 \\
0.7 \\
\leqslant 1.5: \\
1.1 \\
1.4 \\
1.5 \\
\leqslant 1.8: \\
1.6 \\
1.6 \\
1.6 \\
1.7 \\
1.8 \\
1.8 \\
\leqslant 2.6: \\
2.1 \\
2.4 \\
2.5 \\
2.6\end{array}$ & $\begin{array}{l}14 \\
12 \\
10 \\
10 \\
14 \\
10 \\
10 \\
11 \\
19 \\
19 \\
20 \\
22 \\
14 \\
16 \\
10 \\
16\end{array}$ & $\begin{array}{l}150 \\
150 \\
150 \\
150 \\
150 \\
\\
150 \\
150\end{array}$ & $\begin{array}{l}250 \\
250\end{array}$ & $\begin{array}{l}\geqslant 13 \\
\leqslant 12 \\
\leqslant 12 \\
\geqslant 13 \\
\geqslant 13 \\
\leqslant 12 \\
\geqslant 13 \\
\geqslant 13 \\
\geqslant 13 \\
\leqslant 12 \\
\geqslant 13 \\
\leqslant 12 \\
\leqslant 12 \\
\geqslant 13 \\
\geqslant 13 \\
\geqslant 13\end{array}$ & $\begin{array}{l}2 \\
3 \\
2 \\
6 \\
1 \\
2 \\
3 \\
3 \\
2 \\
3 \\
1 \\
2 \\
3 \\
2 \\
3 \\
3\end{array}$ & $\begin{array}{l}\text { Luteinized follicle } \\
\text { No response } \\
\text { Preovulatory follicle } \\
\text { Corpus luteum } \\
\text { Luteinized follicle } \\
\text { Preovulatory follicle } \\
\text { Luteinized follicle } \\
\text { Ovaries larger than normal } \\
\text { Luteinized follicle } \\
\text { Ovaries larger than normal } \\
\text { Preovulatory follicle } \\
\text { Luteinized follicle } \\
\text { Corpus luteum } \\
\text { Ovaries larger than normal } \\
\text { Luteinized follicle } \\
\text { Luteinized follicle }\end{array}$ \\
\hline
\end{tabular}


to that obtained under the same experimental conditions with human menopausal gonadotrophin and human chorionic gnnadotrophin.

We thank Miss Elena Altieri for urinary pregnanediol determinations, Mrs. Elizabeth Grassau for help with the manuscript, and Mr. Rene Roy for photography and illustrations.

The compounds used in this study were generously supplied as follows: Synthetic FSH/LH-RH (AY-24031) from Dr. M. Gahwyler, Ayerst International, New York, N.Y., U.S.A., Medroxyprogesterone Acetate (Depo-Provera) The Upjohn Company, Kalamazoo, Michigan, U.S.A., Chlormadinone Acetate (Gestafortin) Merck, Darmstadt, West Germany.

\section{References}

Akande, E. O., et al. (1972). Lancet, 2, 112.

Kastin, A. J., Schally, A. V., Gual, C., and Arimura, A. (1972 a). Fournal of Clinical Endocrinology and Metabolism, 34, 753.

Kastin, A. J., Gual, C., and Schally, A. V.'(1972 b). Recent Progress in Hormone Research, 28, 201.

Schally, A. V., et al. (1971 a). Science, 173, 1036.

Schally, A. V.., Kastin, A. J., and Arimura, A. (1971 b). Fertility and Sterility, 22, 703 .

Schally, A. V., Kastin, A. J., and Arimura, A. (1972). American fournal of Obstetrics and Gynecology, 114, 423.

Sulimovici, S., Lunenfeld, S., and Shelesnyak, M. C. (1965). Acta Endocrinologica Kpbenhavn, 49, 97.

Yen, S. S. C., et al. (1972). Fournal of Clinical Endocrinology and Metabolism, 34, 1108 .

Zanartu, J., Dabancens, A., Kastin, A. J., and Schally, A. V. (1974). In press.

Zanartu, J., et al. (1970). Fertility and Sterility, 21, 525.

Zanartu, J., and Onetto, E. (1974). Australian and New Zealand fournal of Obstetrics and Gynaecology. In press.

Zarate, A., Canales, E. S., Schally, A. V., Ayala-Valdez, L., and Kastin, A (1972). Fournal of Fertility and Sterility, 23, 672.

\title{
Endoscopic Pancreatography in Management of Relapsing Acute Pancreatitis
}

\author{
P. B. COTTON, J. S. M. BEALES
}

British Medical fournal, 1974, 1, 608-611

\begin{abstract}
Summary
Endoscopic retrograde cholangiopancreatography (E.R.C.P.) was attempted in 31 patients suffering from repeated attacks of acute pancreatitis. Pancreatograms were obtained in 25 patients. Twelve showed definite "surgical lesions" (obstructions, strictures, or pseudocysts). In at least three patients failure to obtain a pancreatogram was due to obstruction of pancreatic duct close to the papilla. Two patients, both with pseudocysts, developed a mild relapse of pancreatitis after the procedure. Surgical intervention based on the x-ray findings seemed beneficial in the short follow-up period.

Endoscopic pancreatography can be of value in deciding when surgery is advisable for patients with relapsing acute pancreatitis and in determining the operative appreach. It is an advance in the management of a difficult clinical condition.
\end{abstract}

\section{Introduction}

In Britain about one-third of patients who survive an attack of acute pancreatitis have at least one recurrence (Trapnell, 1966). In some of them a previously overlooked contributory factor (such as gall stones or alcoholism) is found which may be remediable. In others, however, there is no apparent explanation for their recurrent acute relapses. These cases pose problems in management-in panticular, whether to recommend surgery and what operation. Information about the state of the pancreatic duot and its drainage should be of help. Until recently pancreatography was possible only at laparotomy (Doubilet et al., 1959) after a duodenotomy, which

St. Thomas's Hospital, London SE1 7EH

P. B. COTTON, M.D., M.R.C.P., Senior Medical Registrar (Present appointment: Consultant Physician, Middlesex Hospital, London W.1)

J. S. M. BEALES, M.R.C.P., F.F.R., Consultant Radiologist (Present appointment: Consultant Radiologist, Royal United Hospital, Bath) increased the risk of explanatory surgery. Owing to the recent development of fibreoptic duodenoscopes the papilla of Vater can now be cannulated by endoscopy in conscious, sedated patients and contrast medium for radiography injected into the pancreatic ducts and biliary system. After the original Japanese studies (Ogoshi et al., 1970; Oi et al., 1970; Takagi et al., 1970; Kasugai et al., 1972) many encouraging reports of the technique came from Western Europe and Nonth America (Jean-pierre et al., 1971; Blumgart et al., 1972; Classen et al., 1972; Cotton et al., 1972; Cotton, 1972; Vennes and Silvis, 1972). In experienced hands the success rate is about $90 \%$.

Endoscopic retrograde cholangiography has obvious potential in the diagnosis of patients with difficult jaundice (Blumgant et al., 1972) but the clinical role of endoscopic retrograde pancreatography has yet to be defined. This paper reponts our use of it in cases of relapsing acute pancreatitis and our experience of its value as a guide to their management.

\section{Patients and Methods}

A total of 31 patients were investigated. Five were women (aged 63, 58, 62, 23, and 79 years respectively) and 26 were men (mean age 43 years, range 21-72 years). Two patients came from India, one from Iceland, and the remainder from the United Kingdom and Ireland. Five had had only one major attack of acute pancreatitis but had continued to have recurrent episodes of pain needing funther hospital investigation. The remaining patients had had from two to 20 attacks of acute pancreatitis over a period of up to 15 years. Four patients had undergone cholecysteotomy for stones and another patient had been suspected of having a gall bladder stone on cholecystography. Fifteen of the patients drank alcohol rarely, if at all, nine drank alcohol every day but not excessively, and seven patients regularly drank more than one litre of beer or three (English) measures of spirits daily. None of the patients had hypercalcaemia and none out of 21 patients tested had any striking abnormality of serum cholesterol or triglycerides. Two patients were being treated with thiazide diuretics. Two patients had had surgery for peptic ulcera- 